\title{
Health Risk Assessment of Heavy Metals in Locally Produced Beer to the Population in Ethiopia Tadele Eticha ${ }^{1 *}$ and Ariaya Hymete ${ }^{2}$
}

${ }^{1}$ Department of Pharmacy, College of Health Sciences, Mekelle University, Mekelle, Ethiopia

${ }^{2}$ Department of Pharmaceutical Chemistry and Pharmacognosy, School of Pharmacy, Addis Ababa University, Addis Ababa, Ethiopia

\begin{abstract}
Different beer brands produced in Ethiopia were surveyed for the presence of $\mathrm{Cd}, \mathrm{Cu}, \mathrm{Pb}, \mathrm{Mn}$ and $\mathrm{Zn}$. The samples were digested in nitric acid and hydrogen peroxide, and analysed by atomic absorption spectrometry equipped with deuterium arc background corrector. The mean concentrations of metals in beer were as follows: $\mathrm{Cd}, 0.0014 \mathrm{mg} / \mathrm{l} ; \mathrm{Cu}, 0.0368 \mathrm{mg} / \mathrm{l} ; \mathrm{Mn}, 0.0954 \mathrm{mg} / \mathrm{l} ; \mathrm{Pb}, 0.006 \mathrm{mg} / \mathrm{l} ; \mathrm{Zn}, 1.5206 \mathrm{mg} / \mathrm{l}$. The estimated daily intakes were calculated based on Ethiopian annual per capita beer consumption of 8.75 liters. The mean intakes of $\mathrm{Cd}$, $\mathrm{Cu}, \mathrm{Pb}, \mathrm{Mn}$ and $\mathrm{Zn}$ through beer were estimated to be $0.0006,0.0232,0.0024,0.0378$ and $0.6076 \mu \mathrm{g} / \mathrm{kg}$ bw/day, respectively. The risk assessment of mean levels indicated that health risk associated with these heavy metals through consumption of beer was absent.
\end{abstract}

Keywords: Beer; Estimated daily intake; Heavy metal

\section{Introduction}

Heavy metals are introduced into the environment by both natural and anthropogenic causes. Human activities like metal mining, smelters, shredder plants and waste depositing and incineration have increased the concentration of metals within the natural environment thereby increasing their mobilization to a level exceeding that of their natural concentration. Expansion of industries greatly increased the levels of toxic elements in the environment. Moreover, increased use of chemical fertilizers and pesticides can also lead to an increase in heavy metal concentrations in soil and plants. Accumulation of such metals in soil and plants becomes a serious issue because of the potential human health risks [1-3].

Some heavy metals have nutritional functions and are essential to maintain the metabolism of the human body. Metals like $\mathrm{Cu}, \mathrm{Mn}$ and $\mathrm{Zn}$ are essential for physiological processes; certain enzymes need metal ions for their catalytic activity. On the other hand, $\mathrm{Cd}$ and $\mathrm{Pb}$ are toxic metals. All of them may be harmful if excessive amounts are consumed [2-5]. Cadmium is a highly toxic element that accumulates in biologic systems and has a long half-life. Generally, the Cd content in alcoholic beverages has been found to be quite low; however, when the consumption of large amounts of certain beverages causes the dietary intake of $\mathrm{Cd}$ to reach the maximum allowable levels, it may be physiologically significant [6]. Lead is also a toxic heavy metal widely distributed in the environment. The entry of lead into the food chain is a major concern, because of its toxicity. Lead has strong effects on haem biosynthesis and erythropoiesis $[7,8]$. Even though $\mathrm{Cu}$ is one of the essential elements, its intake at high concentration is associated with oxidative stress, diminished activities of antioxidant enzymes and subsequent tissue damage [9]. Similarly high level of Mn causes toxicity to humans, often called Mn induced parkinsonism [10] while excess amount of $\mathrm{Zn}$ can cause system dysfunctions that results in impairment of growth and reproduction [11].

Humans are exposed to essential and toxic heavy metals from various sources, including the contaminated atmosphere, food, water or soil. Consuming food crops contaminated with metals is a major food chain route for human exposure. This food chain contamination is one of the important pathways for the entry of these toxic pollutants into the human body. For example, food contamination is the most important pathway of $\mathrm{Cd}$ exposure to the general population. People receive the largest portion of their daily $\mathrm{Pb}$ intake through food. Lead can enter food during storage and manufacture, e.g. in canned foods and in alcoholic drinks $[7,12]$.

Metals can be transferred from the soil to plants from which an alcoholic beverage is prepared [13]. Beer is one of the most consumed alcoholic beverages in Ethiopia, yet no data exist on the metal contents of beer produced in Ethiopia. In order to bridge this gap, this study was undertaken to determine the concentrations of $\mathrm{Cd}, \mathrm{Cu}, \mathrm{Pb}, \mathrm{Mn}$ and $\mathrm{Zn}$ in locally produced beer brands, with a view to provide information on the average daily intake of these metals from consumption of these products.

\section{Materials and Methods}

\section{Sample collection}

The samples of locally produced beer brands were collected from ten randomly selected grocery stores in Addis Ababa, the capital city of Ethiopia in February 2011. There are five beer brands (Bedelle, Dashen, St. George, Harar and Meta) that produced in Ethiopia. Beer samples were collected as described by the European Commission [14]. The percentage of alcohol by volume in the samples ranged from 4.5 to $5.5 \%$. The samples were stored at $4^{\circ} \mathrm{C}$ until analysis was completed.

\section{Sample preparation}

Prior to analysis, all beer samples were degassed using an ultrasonic bath for $30 \mathrm{~min}$ [5]. Samples were digested according to the methods described in [15]. Exactly $20 \mathrm{ml}$ of the degassed beer portions were

*Corresponding author: Tadele Eticha, Department of Pharmacy, College of Health Sciences, Mekelle University, Mekelle, Ethiopia, Tel: +251913625938; E-mail: td.eticha@gmail.com

Received November 27, 2014; Accepted December 16, 2014; Published December 20, 2014

Citation: Eticha T, Hymete A (2014) Health Risk Assessment of Heavy Metals in Locally Produced Beer to the Population in Ethiopia. J Bioanal Biomed 6: 065-068. doi:10.4172/1948-593X.1000114

Copyright: $\odot 2014$ Eticha T, et al. This is an open-access article distributed unde the terms of the Creative Commons Attribution License, which permits unrestricted use, distribution, and reproduction in any medium, provided the original author and source are credited. 
digested on a hot plate prior to the determination of heavy metal concentrations. Accordingly, samples were placed into $100-\mathrm{ml}$ glass beakers and covered with watch glasses in order to prevent contamination. To evaporate alcohol and reduce the sample volume to about $1 \mathrm{ml}$, they were allowed to boil at about $100^{\circ} \mathrm{C}$. Care was taken to avoid spattering. Then, $3 \mathrm{ml}$ of concentrated nitric acid (65\% $\mathrm{HNO}_{3}$ ) was added and the samples were evaporated nearly to dryness. After cooling, $5 \mathrm{ml}$ of hydrogen peroxide $\left(30 \% \mathrm{H}_{2} \mathrm{O}_{2}\right)$ was added to the residues and heating was continued until the volume was again reduced to about $1 \mathrm{ml}$. The aliquots left were mixed with little water and diluted to $10 \mathrm{ml}$ for analysis. Analytical blanks were prepared in a similar manner, but omitting the test sample. The solutions were subsequently analyzed for metals using flame atomic absorption spectrometry equipped with deuterium arc background corrector (PG990, United Kingdom).

\section{Quality control}

Appropriate quality assurance procedures and precautions were carried out to ensure the reliability of the results. Samples were handled carefully to avoid contamination. All glassware and other containers were properly cleaned and the reagents were of analytical grade. Distilled deionized water was used throughout the study. Reagent blank determinations were used to correct the instrument readings. Accuracy of the digestion procedures was verified by examination of the recovery data, spiking analyzed samples with aliquots of metal standards and then reanalyzing the samples. The percentage recoveries lay within the range $87.6-104.68 \%$ with the percent relative standard deviations less than eleven, indicating good accuracy and precision. Limits of Detection (LOD) were calculated as three times the pooled standard deviation of six runs of blank measurements. LODs of Cd, $\mathrm{Cu}, \mathrm{Mn}, \mathrm{Pb}$ and $\mathrm{Zn}$ were $0.006,0.011,0.009,0.020$ and $0.042 \mathrm{mg} / \mathrm{kg}$ respectively.

\section{Statistical analysis}

The analysis of variance (ANOVA) and Tukey post hoc test were performed to find differences between the means of samples at 95\% confidence level and to know specifically which groups differed significantly from the other groups. Data were analyzed statistically using SPSS statistical package version 13.0.

\section{Results and Discussion}

\section{Metal content of beer samples}

The mean concentrations ( \pm standard deviations) of metals considered in the different brands of beer and their maximum tolerance limits set by the Brazilian legislation in alcoholic beverages [16] are presented in (Table 1). Bedelle beer contained the highest

\begin{tabular}{|l|c|c|c|c|c|}
\hline Sample & $\mathbf{C d}$ & $\mathbf{C u}$ & $\mathbf{M n}$ & $\mathbf{P b}$ & $\mathbf{Z n}$ \\
\hline Bedelle & ND & $0.016 \pm 0.002$ & $0.202 \pm 0.005$ & ND & $0.779 \pm 0.010$ \\
\hline Dashen & ND & $0.052 \pm 0.006$ & $0.091 \pm 0.007$ & ND & $1.697 \pm 0.019$ \\
\hline St. George & ND & $0.048 \pm 0.002$ & $0.091 \pm 0.004$ & $0.030 \pm 0.002$ & $1.000 \pm 0.008$ \\
\hline Harar & ND & $0.056 \pm 0.002$ & $0.051 \pm 0.002$ & ND & $0.599 \pm 0.025$ \\
\hline Meta & $0.007 \pm 0.001$ & $0.012 \pm 0.000$ & $0.042 \pm 0.005$ & ND & $3.528 \pm 0.051$ \\
\hline Mean & 0.0014 & 0.0368 & 0.0954 & 0.006 & 1.5206 \\
\hline MTL & 0.5 & 5.0 & - & 0.5 & 5.0 \\
\hline
\end{tabular}

ND-Not detected, MTL - maximum tolerance limits of metals in alcoholic beverages established by the Brazilian legislation.

Table 1: Metal concentrations (mg/l) of the analyzed beer samples and their limits in beer. concentration of manganese $(0.202 \mathrm{mg} / \mathrm{Kg})$ among beer brands. Both $\mathrm{Cd}$ and $\mathrm{Pb}$ were not detected in Bedelle beer. Copper $(0.016 \mathrm{mg} / \mathrm{Kg})$ was found at much lower concentration than $\mathrm{Mn}$ and $\mathrm{Zn}$ in this brand. Bedelle beer can contribute to higher $\mathrm{Zn}$ intake than $\mathrm{Cu}$ and $\mathrm{Mn}$ intakes. The mean concentration of $\mathrm{Cu}(0.052 \mathrm{mg} / \mathrm{Kg})$ was also lower than $\mathrm{Mn}$ $(0.091 \mathrm{mg} / \mathrm{Kg})$ and $\mathrm{Zn}(1.697 \mathrm{mg} / \mathrm{Kg})$ in Dashen beer while $\mathrm{Cd}$ and $\mathrm{Pb}$ were not detected in this beer brand. Dashen beer also contributes towards higher $\mathrm{Zn}$ intake than $\mathrm{Cu}$ and $\mathrm{Mn}$ intakes. The only beer brand observed to contain $\mathrm{Pb}$ was St. George $(0.03 \mathrm{mg} / \mathrm{Kg})$. Zinc $(1 \mathrm{mg} / \mathrm{Kg})$ was present at higher concentration in St. George beer than $\mathrm{Mn}(0.091$ $\mathrm{mg} / \mathrm{Kg})$ followed by $\mathrm{Cu}(0.048 \mathrm{mg} / \mathrm{Kg})$. However, Cd was not detected in St. George beer. St. George beer was the only beer that contributed $\mathrm{Pb}$ to the total dietary intake. In Harar beer, the level of $\mathrm{Zn}(0.599 \mathrm{mg} /$ $\mathrm{Kg})$ was higher than $\mathrm{Mn}(0.051 \mathrm{mg} / \mathrm{Kg})$ and $\mathrm{Cu}(0.056 \mathrm{mg} / \mathrm{Kg})$. On the other hand, $\mathrm{Cd}$ and $\mathrm{Pb}$ were not detected in Harar beer. Harar beer brand, like Bedelle and Dashen beers, contributed to higher $\mathrm{Zn}$ intake than $\mathrm{Cu}$ and $\mathrm{Mn}$ intakes. Meta beer was the only beer observed to contain $\mathrm{Cd}(0.007 \mathrm{mg} / \mathrm{Kg})$. It also contained the highest concentration of $\mathrm{Zn}(3.528 \mathrm{mg} / \mathrm{Kg})$. In contrast, $\mathrm{Cu}(0.012 \mathrm{mg} / \mathrm{Kg})$ and $\mathrm{Mn}(0.042$ $\mathrm{mg} / \mathrm{Kg}$ ) were present in Meta beer at the lowest concentrations than the other brands of beer. Meta beer was the only beer that contributed Cd to the total dietary intake.

The concentrations of $\mathrm{Cd}, \mathrm{Cu}, \mathrm{Pb}$ and $\mathrm{Zn}$ in the different brands of beer were below the regulatory limits for alcoholic beverages set by the Brazilian legislation. The concentration of heavy metals in beer is also recommended not to exceed the maximum permissible limits in drinking water since beer contains more than 90 percent of water [16]. However, limits imposed for alcoholic beverages are higher than those established for water utilized for human consumption due to lower intake of the former [13]. Since limit for $\mathrm{Mn}$ in alcoholic beverages has not been set by the Brazilian legislation, its levels were compared with permissible limits in drinking water. Manganese contents of the beer samples were below the WHO maximum permissible limits in drinking water, $0.4 \mathrm{mg} / \mathrm{l}[17]$.

The level of metals in beers is highly affected by the soil type on which the cereal grains are cultivated, the use of fertilizers, pesticides and fungicides, and the surrounding environmental pollution [13]. Chen et al. [18] reported that there are differences among the barley varieties in their ability to accumulate heavy metals in grains. Moreover, brewing water is the source of heavy metals such as $\mathrm{Cd}$ and $\mathrm{Pb}$ found in beer [19]. During the brewing process, the metal content of beer could be also affected by the components of the brewery equipment like pipes, fluid lines, vessels and tanks, and other materials involved in the process [20]. Cadmium in beer and other alcoholic beverages could be due to raw material contamination and technological processes [6]. Zinc may originate in the raw materials, brewing liquor or substances added during brewing. Small amounts of zinc may be also picked up from the brewing plant [21].

\section{Comparison of the metal levels in beer samples with reported data}

A comparison of the results obtained in this study with values found in literature is presented in (Table 2). The concentration of Cd in the present study is comparable to the levels reported in beers available in Nigeria [22], Italy [5] and Brazil [23]. The levels of $\mathrm{Cu}$ obtained in this work are in agreement with that of other studies in Nigeria [22], Brazil [24] and Norway [25]. The lead level observed in this study is in line with that of other surveys $[5,22,24]$. For $\mathrm{Mn}$ the results obtained in this work are comparable to the levels reported in beers from Poland 


\begin{tabular}{|l|c|c|c|}
\hline Metal & Source & Concentration(mg/l) & Reference \\
\hline Cadmium & Nigeria & ND-0.01 & {$[22]$} \\
\hline & Italy & ND -0.00058 & {$[5]$} \\
\hline & Brazil & ND -0.0143 & {$[23]$} \\
\hline & Ethiopia & ND -0.007 & Present study \\
\hline Copper & Nigeria & $0.04-0.10$ & {$[22]$} \\
\hline & Brazil & $0.038-0.155$ & {$[24]$} \\
\hline & Norway & $0.007-0.049$ & {$[25]$} \\
\hline & Ethiopia & $0.012-0.056$ & Present study \\
\hline Lead & Nigeria & ND -0.047 & {$[22]$} \\
\hline & Italy & ND -0.0133 & {$[5]$} \\
\hline & Brazil & $0.013-0.0329$ & {$[24]$} \\
\hline & Ethiopia & ND -0.03 & Present study \\
\hline Manganese & Poland & $0.12-0.24$ & {$[26]$} \\
\hline & Brazil & $0.11-0.348$ & {$[24]$} \\
\hline & Norway & $0.032-0.142$ & {$[25]$} \\
\hline & Ethiopia & $0.042-0.202$ & Present study \\
\hline Zinc & Nigeria & $0.010-0.15$ & {$[22]$} \\
\hline & Poland & $0.019-0.037$ & {$[26]$} \\
\hline & Brazil & $0.0527-0.226$ & {$[24]$} \\
\hline & Ethiopia & $0.599-3.528$ & Present study \\
\hline
\end{tabular}

Table 2: Comparison of levels of metals in beer samples $(\mathrm{mg} / \mathrm{l})$ reported from different countries.

\begin{tabular}{|c|c|c|}
\hline Metal & EDI $(\boldsymbol{\mu g} / \mathbf{k g}$ bw/day $)$ & TDI $(\boldsymbol{\mu g} / \mathbf{k g}$ bw/day $)$ \\
\hline $\mathrm{Cd}$ & 0.0006 & 1 \\
\hline $\mathrm{Cu}$ & 0.0232 & 166.7 \\
\hline $\mathrm{Mn}$ & 0.0378 & 183.3 \\
\hline $\mathrm{Pb}$ & 0.0024 & 3.6 \\
\hline $\mathrm{Zn}$ & 0.6076 & 666.7 \\
\hline
\end{tabular}

Table 3: Estimated exposure to $\mathrm{Cd}, \mathrm{Cu}, \mathrm{Pb}, \mathrm{Mn}$ and $\mathrm{Zn}$ for the general population in beer and their $\mathrm{FAO} / \mathrm{WHO}$ tolerable daily intake.

[26], Brazil [24] and Norway [25]. However, Zn levels observed in beers produced in Ethiopia are higher than the values found in beers from other origins $[22,24,26]$. Generally, the quality and safety of the local beers investigated are in agreement with that of beers available in Brazil, Italy, Nigeria, Norway and Poland in terms of $\mathrm{Cd}, \mathrm{Cu}, \mathrm{Pb}, \mathrm{Mn}$ and $\mathrm{Zn}$ levels.

\section{Statistical analysis for significance of differences between means}

Analysis of variance indicated that there were significant $(\mathrm{p}<0.05)$ differences between beer brands for their manganese, copper and zinc content, whereas Tukey post-hoc test revealed that Bedelle beer had significantly higher mean manganese content. Dashen, St. George and Harar beers had significantly higher mean concentration of copper and Meta beer contained a significantly higher level of zinc. Mean values for manganese showed no significant difference between Dashen and St. George beers, and Harar and Meta beers. Similarly, the copper contents of Bedelle and Meta, Dashen and St. George, Dashen and Harar, and St. George and Harar beers were not significantly different. On the other hand, there existed statistically significant differences among the means of zinc content of the five brands of beer. Harar and Meta beers had significantly lower mean values of manganese; and Bedelle and Meta beers contained significantly lower levels of copper. The lowest level of zinc was significantly observed in Harar beer brand.

Therefore, the contribution of Meta beer to the total copper and manganese intake is lower than other brands though it contributes higher levels of zinc. Copper intake from Bedelle beer is also lower but the manganese intake from this brand is higher than other beer brands. On the other hand, Harar beer contributes lower levels of manganese and zinc.

\section{Human exposure to heavy metals through beer}

The estimated daily intake of metals was calculated based on the amount of beer daily consumed and heavy metal levels of the beer samples. Ethiopian annual per capita consumption of beer was 8.75 liters per person aged 18 and over (Ethiopian legal drinking age) in 2008 with estimated country wide consumption of 3.1 million hectoliters $[27,28]$. The estimated daily intakes through beer are shown in (Table 3).

All the estimated daily intakes of the target metals calculated based on annual per capita beer consumption were below the tolerable daily intake set by the World Health Organization and hence they could not cause any negative health impact on the consumers. The health risk index (HI) described by the percentage of the safe value was used for the risk assessment. As shown in Table 3, the data of HI were all less than 1 for the mean exposure, which indicated that there was no potential health risk to general people.

\section{Conclusion}

This survey showed that the mean levels of $\mathrm{Cd}, \mathrm{Cu}, \mathrm{Pb}, \mathrm{Mn}$ and $\mathrm{Zn}$ in different locally produced beer brands were below the maximum tolerable limits in alcoholic beverages established by the Brazilian legislation. The mean daily exposures were estimated based on annual per capita beer consumption to be safe. Therefore, contribution of the investigated brands of beer to the dietary exposure of heavy metals does not pose a health risk to consumers with regard to these elements.

\section{Acknowledgement}

The following universities were acknowledged: The Mekelle University for granting study leave to Mr. Tadele, and Addis Ababa University for financially supporting this study.

\section{References}

1. Khan S, Cao Q, Zheng YM, Huang YZ, Zhu YG (2008) Health risks of heavy metals in contaminated soils and food crops irrigated with wastewater in Beijing, China. Environ Pollut 152: 686-692.

2. Pizzol M, Christensen P, Schmidt J, Thomsen M (2011) Impacts of "metals" on human health: a comparison between nine different methodologies for Life Cycle Impact Assessment (LCIA). J Cleaner Production 19: 646-656.

3. Hang X, Wang H, Zhou J, Maa C, Du C et al. (2009) Risk assessment of potentially toxic element pollution in soils and rice (Oryza sativa) in a typical area of the Yangtze River delta. Environ Pollut 157: 2542-2549.

4. Eren E, Arguello JM, Weathers P, Wobbe KK (2006) HMA. A transmembrane $\mathrm{Zn}^{2+}$ transporting ATPase from Arabidopsis thaliana. Worcester Polytechnic Institute, A Ph.D. dissertation.

5. Donadini G, Spalla S, Beone GM (2008) Arsenic, cadmium and lead in beers from the Italian market. J Inst Brew 114: 283-288.

6. Mena C, Cabrera C, Lorenzo ML, Lopez MC (1996) Cadmium levels in wine beer and other alcoholic beverages: possible sources of contamination. Sci Total Environ 181: 201-208.

7. Silva ALO, Barrocas PRG, Jacob SC, Moreira JC (2005) Daily intake and health effects of selected toxic elements. Braz J Plant Physiol 17: 79-93.

8. Food Safety Authority of Ireland (2009) Mercury, lead, cadmium, tin and arsenic in food. Toxicol factsheet series, Dublin, Ireland.

9. Uriu-Admas $Y$, Keen $L$ (2005) Copper, oxidative stress and human health. Mol Aspect Med 26: 268-298.

10. Finley JW (2004) Does environmental exposure to manganese pose a health risk to healthy adults? Nutr Rev 62: 148-153.

11. Duruibe JO, Ogwuegbu MOC, Egwurugwu JN (2007) Heavy metal pollution and human biotoxic effects. Int J Phys Sci 2: 112-118. 
Citation: Eticha T, Hymete A (2014) Health Risk Assessment of Heavy Metals in Locally Produced Beer to the Population in Ethiopia. J Bioanal Biomed 6: 065-068. doi:10.4172/1948-593X.1000114

12. Celechovska O, Malota L, Zima S (2008) Entry of heavy metals into food chains: a 20-year comparison study in Northern Moravia (Czech Republic). Acta Vet Brno 77: 645-652.

13. Ibanez JG, Carreon-Alvarez A, Barcena-Soto M, Casillas N (2008) Metals in alcoholic beverages: A review of sources, effects, concentrations, removal, speciation, and analysis. J Food Compos Anal 21: 672-683.

14. European Commission (2006) Commission regulation (EC) No 401/2006 of 23 February 2006 laying down the methods of sampling and analysis for the official control of the levels of mycotoxins in foodstuffs. Off J Eur Union L 70: 12-34.

15. Pohl P and Prusisz B (2010) Chemical fractionation of $\mathrm{Cu}, \mathrm{Fe}$ and $\mathrm{Mn}$ in canned Polish beers. J Food Compos Anal 23: 86-94.

16. Moreira S, Vives AE, Zucchi OL, Jesus EF, Filho VF et al. (2006) Analysis of beers from Brazil with synchrotron radiation total reflection X-ray fluorescence. J Radioanal Nuclear Chem 270: 167-171.

17. WHO (2008) Guidelines for drinking water quality, Geneva, Switzerland.

18. Chen F, Dong J, Wang F, Wu F, Zhang G, et al. (2007) Identification of barley genotypes with low grain $\mathrm{Cd}$ accumulation and its interaction with four microelements. Chemosphere 67: 2082-2088.

19. Hughes PS, Baxter ED (2001) Beer: quality, safety and nutritional aspects. Royal Society of Chemistry, Cambridge, p. 128.

20. Pohl $P$ (2008) Determination and fractionation of metals in beer: A review. Food Additi Contam 25: 693-703.
21. Briggs DE, Boulton AC, Brookes AP, Stevens R (2004) Malts, adjuncts and supplementary enzymes, Brewing Science and practice. Woodhead Cambridge, UK, p. 30-34.

22. Iwegbue CMA (2010) Composition and daily intakes of some trace metals from canned beers in Nigeria. J Inst Brew 116: 312-315.

23. Soares LMV, Moraes AMM (2003) Lead and cadmium content of Brazilian beers. Cienc Tecnol Alimen Campinas 23: 285-289.

24. Nascentes CC, Kamogawa MY, Fernandes KG, Arruda MAZ, Nogueira ARA, et al. (2005) Direct determination of $\mathrm{Cu}, \mathrm{Mn}, \mathrm{Pb}$, and $\mathrm{Zn}$ in beer by thermospray flame furnace atomic absorption spectrometry. Spectrochimica Acta Part B 60: 749-753.

25. Asfaw A, Wibetoe G (2005) Direct analysis of beer by ICP-AES: A very simple method for the determination of $\mathrm{Cu}, \mathrm{Mn}$ and Fe. Microchim Acta 152: 61-68.

26. Pohl P, Prusisz B (2007) Fractionation analysis of manganese and zinc in beers by means of two sorbent column system and flame atomic absorption spectrometry. Talanta 71: 1616-1623.

27. International Center for Alcohol Policies (2010) Minimum age limits worldwide. Accessed on August 02, 2011.

28. Access Capital Research (2010) Sector Report-Beer, Accessed on October 17, 2010. 